\title{
Understanding spectator sustainable transportation intentions in international sport tourism events
}

\author{
Rute Martins $^{\mathrm{a}, \mathrm{f}}$ (D), Elsa Pereira ${ }^{\mathrm{b}}$ (D) António Rosadoc ${ }^{\mathrm{D}}$, João Marôco ${ }^{\mathrm{d}}$, Brian \\ McCullough $^{\mathrm{e}}$ (D) and Margarida Mascarenhas ${ }^{f}$ (D) \\ ${ }^{\mathrm{a}}$ Faculty of Human Kinetics, University of Lisbon, Lisbon, Portugal; ${ }^{\mathrm{b}} \mathrm{S}$ chool of Education and \\ Communication, Research Centre for Tourism, Sustainability and Well-Being (CinTurs), University of Algarve, \\ Faro, Portugal; ' ${ }^{C}$ aculty of Human Kinetics, Interdisciplinary Centre for the Study of Human Performance

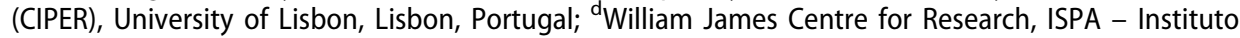 \\ Universitário, Lisbon, Portugal; ${ }^{\mathrm{e}} \mathrm{Health} \&$ Kinesiology, Sport Ecology Laboratory, Texas A\&M University, \\ College Station, TX, USA; ${ }^{f}$ Research Centre for Tourism, Sustainability and Well-Being (CinTurs), University of \\ Algarve, Faro, Portugal
}

\begin{abstract}
It is vital to study spectator responses to environmental campaigns to advance environmental sustainability initiatives. Therefore, this investigation aimed to identify which factors influence spectator sustainable transport intentions and perform a spectator segmentation based on their responses. Data were collected from 355 spectators at an international surfing event hosted in a renowned surfing destination. The data were analysed in two stages. First, through the sport sustainability campaign evaluation model to infer spectator sustainable transport intentions. Second, through non-hierarchical cluster analysis, to segment the sample based on those intentions. The results added a direct relationship between the points of attachment and sustainable transport intentions. Furthermore, the results highlighted the effect of constraints, points of attachment and past sustainable behaviours as predictors of spectator sustainable transport intentions. In addition, differences in needs (i.e., aesthetic), attachment to the community, lack of time, lack of access and past sustainable behaviours were found within the three analysed clusters. Organisers of sport tourism events should develop sustainable transport campaigns promoting the destination's aesthetic features, strengthening the connection between the local community and the event spectators, and improving the availability of information on transport services to increase spectator commitment to more sustainable modes of transport.
\end{abstract}

\section{ARTICLE HISTORY}

Received 23 February 2021 Accepted 5 October 2021

\section{KEYWORDS}

Consumer's environmental behaviour; environmental sustainability; spectators; surf events; sport tourism; sustainable transportation

\section{Introduction}

The study of environmental behaviour has been extended to many tourism industry segments beyond its initial focus on ecotourism. One extension includes encouraging environmental behaviours through the relationship of the tourist with the destination and educating tourists on environmental awareness (Bilynets \& Cvelbar, 2020). Furthermore, scientific research examining the demand for sport tourism has focused on the predictive factors of environmental behaviour

CONTACT Rute Martins rute.grila@gmail.com E Faculty of Human Kinetics, University of Lisbon, Estrada da Costa, 1495-751 Cruz Quebrada, Lisboa, Portugal. 
(Mascarenhas et al., 2021). Hence, environmental attitudes and the attitude-behaviour gap are most relevant (Juvan \& Dolnicar, 2014; Martins et al., 2021). However, further inquiry is needed to improve environmental behaviours because transportation is commonly the most significant percentage of an event's carbon footprint (Mascarenhas et al., 2021; Peeters et al., 2019). Prior transportation research examining sport tourism has primarily assessed the carbon emissions of sport events resulting from participants and spectator transport choices to get to an event (Dolf \& Teehan, 2015; Edwards et al., 2016; Pereira et al., 2019; Triantafyllidis et al., 2018). Nevertheless, few scientific examinations have been dedicated to sport spectators' sustainable transportation behaviours at destinations (i.e., events; Mascarenhas et al., 2021; McCullough et al., 2020 ).

The potential for sport events to leverage environmental sustainability has also been encouraged through raising the sport community's awareness and implementing environmental strategies and measures (International Olympic Committee, 2012; United Nations Environment Programme, 2019; World Tourism Organization, 2019). Consequently, sport event organisers use marketing strategies to use environmental education initiatives and campaigns for sporting events (Barrett et al., 2019; Choi, 2016; McCullough et al., 2016). These campaigns can also include sponsors to promote environmental behaviour change in spectators' daily lives (Casper et al., 2020). However, given the difficulty of sporting events to encourage tourists to use sustainable transportation options (Malhado \& Rothfuss, 2013), it is necessary to study the underlying behavioural factors (Triantafyllidis et al., 2018) as well as the alignment between the sustainable transport campaigns and the target audience (Martin et al., 2017; Tölkes, 2018).

Prior research has predominately focused on North American contexts (Casper et al., 2014, 2017, 2020; Trail \& McCullough, 2020, 2021), and as a result, the boundaries of these previous frameworks and models are unknown and should be further scrutinised in new contexts to evaluate the robustness to advance theory (Bacharach, 1989; Whetten, 1989). Moreover, the inclusion of sport consumer behaviour models into sport tourism contexts extends the interdisciplinary ability to leverage new frameworks to understand specific phenomena (e.g., sustainable behavioural change; Hinch \& Higham, 2001). Within the context of this investigation, the limited number of studies on the behaviour of sport spectators regarding sustainable transport justifies the exploratory nature of this study and its objective. Thus, this study aimed to identify which factors influence spectator sustainable intentions and perform a spectator segmentation based on the latter within a sport tourism context using the sustainable sport consumer evaluation model ( SSCEM; Trail \& McCullough, 2020, 2021).

\section{Literature review}

\section{Sustainable transportation}

In this study, sustainable transport is anchored in the environmental pillar of sustainability, defined as a "system of mobility where (i) generally accepted objectives for health and environmental quality (...) are met, (ii) ecosystem integrity is not significantly threatened and (iii) potentially adverse global phenomena such as climate change (...) are not aggravated" (Friedl \& Steininger, 2002, p.165). The use of public/shared transport is a significant action that can decrease the adverse environmental impacts of tourism (Chirieleison et al., 2020). Shuttle bus service is an alternative to mitigate traffic, parking saturation, and environmental impacts in natural and coastal areas (Antolín et al., 2019; González et al., 2019; Shiftan et al., 2006). However, planning strategies and initiatives to decrease car use must overcome behavioural constraints to choosing more sustainable alternatives. For example, such constraints include the time-cost relationship (i.e., search time for parking, wait time for the shuttle bus; Antolín et al., 2019; González et al., 2019; Le-Klähn \& Hall, 2015; Scuttari et al., 2019 ). Additionally, non-local visitors are more willing to pay for a shuttle bus service in natural areas than local visitors (Shiftan et al., 2006). 


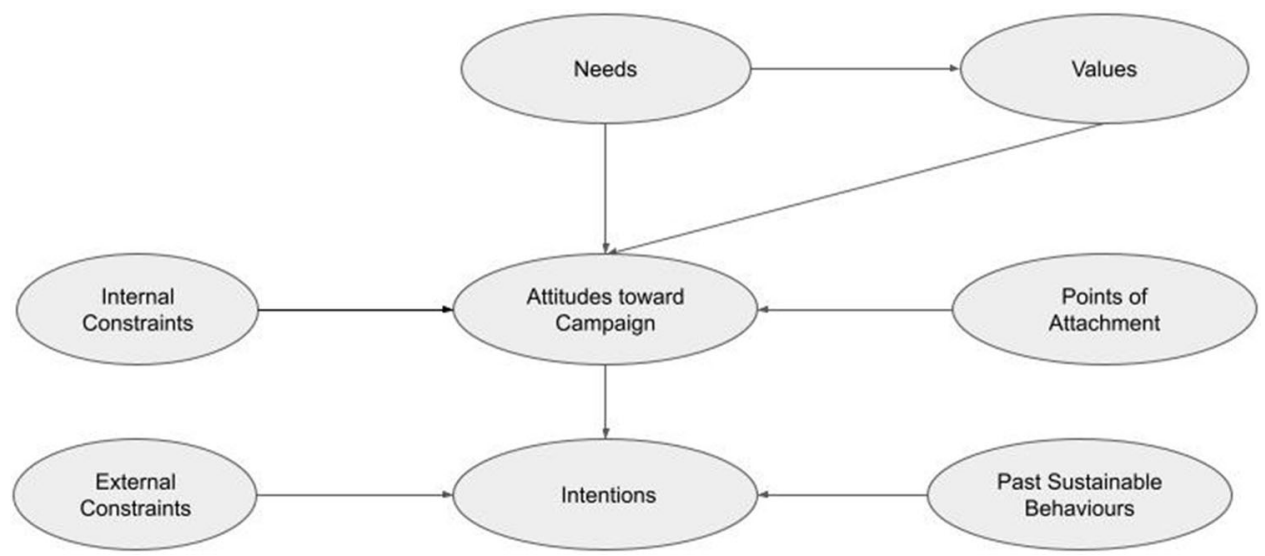

Figure 1. Sport sustainability campaign evaluation model (Trail \& McCullough, 2020, p. 4).

Sporting events have promoted sustainable transport options, such as the World Orienteering Championship (Scrucca et al., 2016), the USA Special Olympic Games in Seattle (Trail \& McCullough, 2021), and the Tokyo Olympic Games (Chen et al., 2018). However, it is challenging to encourage tourists at sporting events to use public and sustainable modes of transportation (Malhado \& Rothfuss, 2013), thereby justifying the realisation of campaigns and the study of spectator sustainable transport choices (Triantafyllidis et al., 2018).

\section{Sport sustainability campaign evaluation model}

Trail (2016) proposed the sport fan sustainability behaviour model to study spectator sustainability intentions, but the model has not yet been extensively tested. Following the same research line, the sport sustainability campaign evaluation model (SSCEM) was created to study the effect of environmental campaigns on the sustainability behaviour intentions of the sport actors (Trail \& McCullough, 2020). The SSCEM advocates values, needs, internal constraints and points of attachment as predictors of attitudes towards the campaign and attitudes towards the campaigns, past sustainable behaviours and external constraints as predictors of sustainability intentions (Figure 1; Trail \& McCullough, 2020).

To produce the SSCEM, Trail and McCullough (2020) draw from multiple theories, including the theory of planned behaviour (TPB; Ajzen \& Madden, 1986), value-norm-belief (Stern et al., 1999), and identity theory (Stryker \& Burke, 2000). These theories informing the SSCEM have theoretically supported and empirically demonstrated the influence of needs, values, points of attachment, attitudes, and past behaviours on sustainable behaviours. Further, constraint models (Kim \& Trail, 2010; Trail \& McCullough, 2018) substantiate the negative influence of internal and external constraints on sustainable behaviours.

\section{Values, needs and attitudes}

The distinguishing feature of the theory of fundamental human values (Schwartz, 1992) is the appreciation for tolerance and protection of the welfare of all people and nature. For example, universal and biospheric values are significant predictors of pro-environmental behaviours (de Groot \& Steg, 2010), including sport spectators (Casper et al., 2014, 2017, 2020; Gau et al., 2019). For example, Trail and McCullough (2020) found a positive relation between universalism values and sport participant attitudes towards a sustainability campaign for a sporting event.

Based on Maslow's hierarchy of needs, self-actualisation needs relate to personal growth. Trail (2019) studied the sport consumer's needs, including wisdom, inner peace, and aesthetics, 
extending this hierarchy. Trail defined the latter as the 'natural beauty inherent in the world or the aesthetical aspects of life' (p. 217). Previously, Trail (2016) had verified that those self-actualisation needs were related to the sport spectators' environmental sustainability intentions as mediated by environmentalism, tolerance, and social justice values.

From a generalist perspective, TPB (Ajzen \& Madden, 1986) determines whether or not attitudes are predictors of intentions and behaviours. For example, in a sport tourism context, environmental attitudes are associated with a positive effect on sport practitioners' environmental activism and knowledge (Kil et al., 2014) and spectators' recycling behaviours (McCullough, 2013). This theory has also been applied in leisure studies examining the choice of less environmentally harmful transportation alternatives (Meng \& Choi, 2016; Zailani et al., 2016).

Accordingly:

$H_{1}$ : Self-actualisation needs will influence universalism values.

$\mathrm{H}_{2 \mathrm{a}}$ : Self-actualisation needs will influence attitudes towards the campaign.

$\mathrm{H}_{2 \mathrm{~b}}$ : Self-actualisation needs will influence attitudes towards the campaign mediated by universalism values.

$\mathrm{H}_{3}$ : Universalism values will influence attitudes towards the campaign.

$\mathrm{H}_{4}$ : Attitudes towards the campaign will lead to sustainable transport intentions.

\section{Points of attachment}

Points of attachment are the nodes or connections an individual develops with an external entity (e.g., event, community; Trail et al., 2005). Points of attachment can be leveraged to influence sport consumer behaviour (Ballouli et al., 2016; Rocha \& Fleury, 2017; Trail et al., 2005). For example, points of attachment (e.g., athlete, team, event, place) influence attendance intentions (Ballouli et al., 2016) and environmental sustainability behaviours at an event (Casper et al., 2020) and in everyday life (Trail \& McCullough, 2021). The pro-environmental identity role has also been highlighted with respect to sustainable transport options (Whitmarsh \& O'Neill, 2010) in a tourism context (Hibbert et al., 2013). Therefore:

$\mathrm{H}_{5}$ : Points of attachment will influence attitudes towards the campaign.

\section{Past behaviour and constraints}

Constraints and previous behaviours also negatively and positively influence behaviours, respectively. Environmental behavioural research has also influenced these factors (Han, 2021), including the choice of greener transport (Whitmarsh \& O'Neill, 2010). In addition, event management studies have found a positive link between past behaviours and sport spectator behavioural intentions (McCullough \& Cunningham, 2011) and visitors' adoption of sustainable modes of transportation to events (Collins \& Potoglou, 2019).

Internal and external constraints have negatively influenced sport consumption (Kim \& Trail, 2010; Rocha \& Fleury, 2017). Internal constraints are internal psychological barriers that dissuade behaviour, such as lack of knowledge, lack of worth and lack of time (Trail \& McCullough, 2018). Conversely, external constraints are external environmental factors that need to be overcome to engage in behaviour, such as cost and lack of access (Trail \& McCullough, 2020). Specific to sustainable transportation behaviours, the lack of information (i.e., internal constraint) and the lack of service availability (external constraint) dissuade tourists from using sustainable transportation at sporting events (Malhado \& Rothfuss, 2013). Further, Trail and McCullough (2018) found that internal and external constraints negatively influence sustainable behaviour at sporting events. Correspondingly: 
$\mathrm{H}_{7}$ : Internal constraints will negatively influence attitudes towards sustainability campaigns.

$\mathrm{H}_{8}$ : External constraints will negatively influence sustainable transport intentions.

\section{Spectator segmentation}

Segmentation is a powerful marketing tool used to understand demand based on specific characteristics that create separate groups (Dolnicar et al., 2018; Kotler et al., 2006). Market segmentation allows specific messages to be created to appeal to the group's unique characteristics resulting in more targeted and impactful communications (Trail, 2016). Spectators are an important share of the demand for sport tourism, and their segmentation has been claimed in favour of implementing environmental sustainability (Mascarenhas et al., 2021) and the effectiveness of ecological campaigns (Klöckner, 2015). Thus, segmentation can focus on several characteristics to find similarities between populations, namely demographic, geographical, behavioural and psychographic features.

Although studies on the distinctive characteristics of sport consumer environmental sustainability intentions are scarce, these findings indicate that surfers exhibit such intentions (Frank et al., 2015), which are even more pronounced when compared with those of non-surfers (Larson et al., 2018). Within sporting events, Trail and McCullough (2018) found differences between the sport participants' environmental intentions based on the impact of perceived constraints (i.e., lack of knowledge, worth, access, no interest from others). Additionally, willingness to pay for greener initiatives at sporting events differed among sport participants based on age, level of education, and income (Saayman et al., 2016). Also, the female spectators more positively identified environmental topics proposed at sporting events (Casper et al., 2017). Wicker (2018) revealed that tourists with more income and more frequent sport activities chose a less environmentally friendly mode of transport (e.g., single-use car).

However, segmentation based on sociodemographic characteristics within a tourism context is less predictable and requires a more comprehensive approach (Prillwitz \& Barr, 2011). This can be reached through sustainable marketing's holistic approach to consumer behaviour by integrating the complexity of environmental behaviour into marketing strategy (Peattie \& Belz, 2010). Consequently:

\footnotetext{
$\mathrm{H}_{9 a}:$ Spectators with sustainable transport intentions will present different results for self-actualisation needs, constraints, points of attachment and past sustainable transport behaviours compared to spectators without sustainable transport intentions.
}

$\mathrm{H}_{9 \mathrm{~b}}$ :Spectators with sustainable transport intentions will present different results for universalism values than spectators without sustainable transport intentions.

$\mathrm{H}_{10}$ : Spectators with sustainable transport intentions will present different sociodemographic and sport behavioural characteristics than spectators without sustainable transport intentions.

Using the SSCEM (Trail \& McCullough, 2020), the objective of this investigation was to identify which factors influence spectator sustainable transport intentions and, based on those results, perform consumer (i.e., spectator) segmentation. Thus, this study presents a macro perspective to understand spectator response to a campaign promoting sustainable transport, followed by a segmentation based on the criterion of sustainable behavioural intentions.

\section{Material and methods}

According to the study's purpose, its methodological design first tested hypotheses $\mathrm{H}_{1}$ through $\mathrm{H}_{8}$ based on SSCEM (Trail \& McCullough, 2020) through structural equation modelling (SEM). Based on the results of spectator sustainable transport intentions and the sociodemographic 


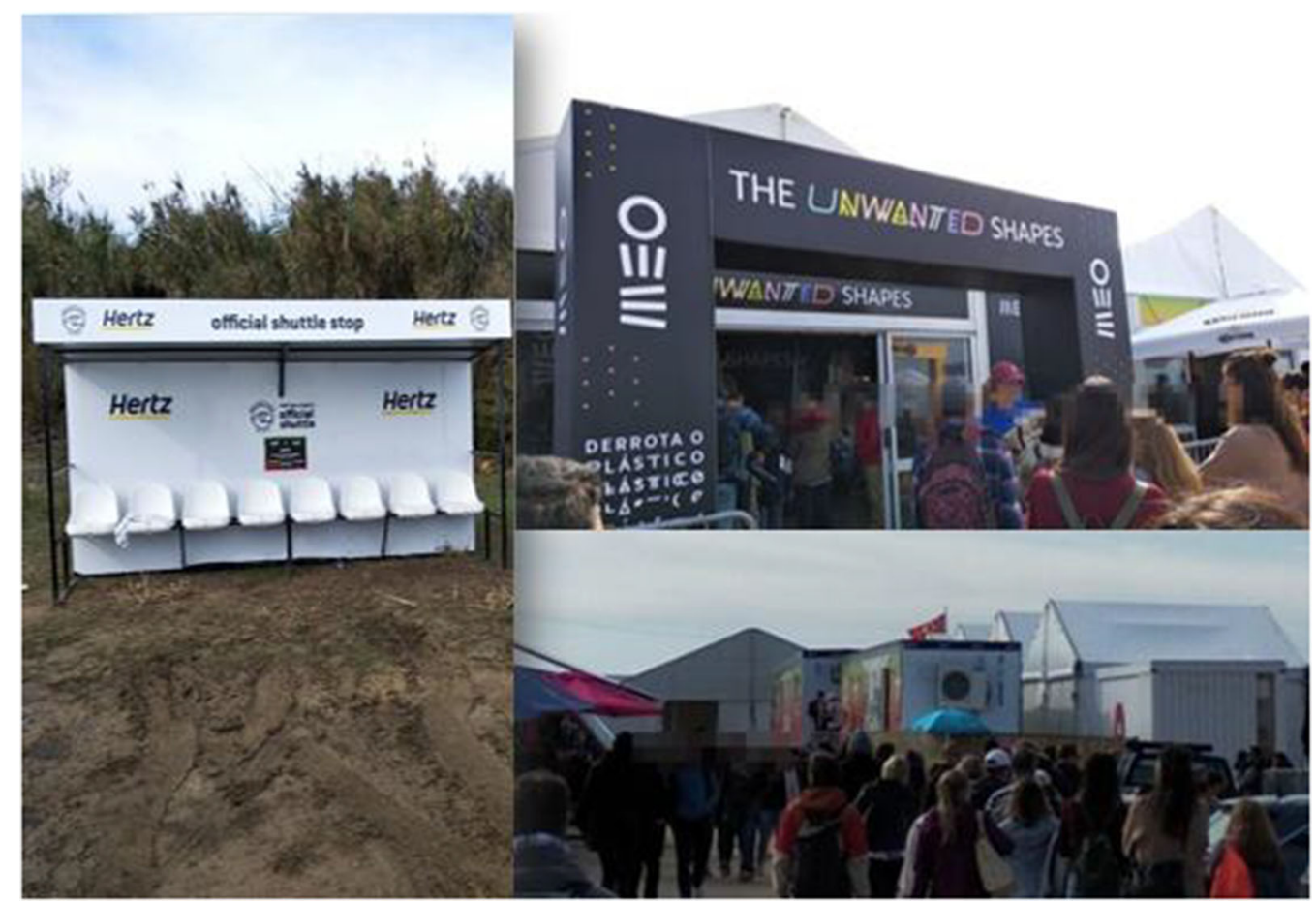

Figure 2. Event context.

variables, a spectator segmentation was then outlined using the K-means cluster analysis to verify hypotheses $\mathrm{H}_{9}$ and $\mathrm{H}_{10}$.

\section{Event context}

Portugal has become an international surfing destination, hosting major international events to anchor surf to the destination image and leverage coastal tourism (Portugal Tourism Board, 2017), such as the Nazaré big wave contest or world championship tour in Peniche. In addition, as a tourism development strategy, Peniche has integrated surfing and its sporting subculture (Teixeira, 2017), and it is involved in the certification of a sustainable surf destination (STOKE., 2020).

The surf community is connected to nature and active in its defence (Wheaton, 2007, 2010). Expectably, the World Surf League (WSL) joined a worldwide platform to promote climate awareness and action among global citizens by the sport community (United Nations Framework Convention on Climate Change, 2018), committed to putting on carbon-neutral events (WSL, 2019b) and promoted the adoption of sustainable transport (WSL, 2019a). Together with the local council as a co-organiser and several local and international sponsors and suppliers, the WSL organised the MEO Rip Curl PRO 2019 at Supertubos beach - Peniche, which is a stage of the World Championship Tour that has been hosted in Portugal since 2009. The event involved 54 international male and female surfers and a sport staff team of 300 persons. Among other environmental campaigns, event organizers provided a shuttle bus service (Figure 2) to transport the staff and guests to the event and transport spectators from the surrounding car parking areas to the event area. Each car parking area had a collaborator to guide the spectators who wished to take the shuttle bus to the event. 
Table 1. Sample sociodemographic and sport activity characteristics.

\begin{tabular}{llrr}
\hline & & Total $(\mathrm{n})$ & Total $(\%)$ \\
\hline Gender $(\mathrm{n}=354)$ & Male & 170 & 48 \\
& Female & 184 & 52 \\
Age $(\mathrm{n}=321)$ & Under 25 & 107 & 33.3 \\
& $25-30$ & 100 & 31.2 \\
& $31-40$ & 67 & 20.9 \\
Level of Education $(\mathrm{n}=351)$ & 41 or more & 47 & 14.6 \\
& High school & 81 & 23.1 \\
& Undergraduate & 125 & 35.6 \\
Sport Activity $(\mathrm{n}=354)$ & Graduate & 142 & 40.5 \\
& Other & 3 & .9 \\
& Active (other sports) & 159 & 44.9 \\
& Active (surf) & 138 & 39.0 \\
& None & 57 & 16.1 \\
\hline
\end{tabular}

\section{Sampling}

The required sample met the criteria type one $(\alpha=.05)$ with a desired statistical power level of .80; medium effect size. The observations that contained $10 \%$ or more missing values were excluded (Enders, 2010), remaining 355 questionnaires for analysis. The sample (Table 1) is primarily young, educated - most have a university education - and active - 39\% surf.

Data collection was carried out in loco, using paper and pen to answer questionnaires and included spectators over 18 years of age, randomly selected from the public. It was performed during the event, on weekdays and weekends, by a team of collaborators who covered the various areas of the beach where spectators could watch the competition. Following a brief presentation of the investigation to the respondents, the collaborators provided the necessary time and space for respondents to complete the questionnaire.

\section{Instrument}

Since the SSCEM (Trail \& McCullough, 2020) was the chosen model to measure spectator sustainable transport intentions, the formulation of the hypotheses and the measurement instrument was adapted to account for specific event context and the sustainable campaign. Thus, the questionnaire measured the self-actualisation needs dimension through the needs for wisdom, inner peace and aesthetics and the universalism values dimension through social justice, tolerance and environmentalism. The items were selected for their representativeness (highest factor loader) per Trail and McCullough (2020). The inclusion of the needs for aesthetic and environmentalism was justified by recognising their contribution to environmental behaviour (Casper et al., 2017; Trail, 2019). Attitudes towards the campaign were measured through two items that characterised attitudes at the surfing event towards specific campaigns and initiatives to promote sustainable behaviour.

Points of attachment were conceptualised as a higher-order factor reflected in attachment to the surfers, attachment to the sport, attachment to the level of the sport and attachment to the community. Each factor was measured by three items based on the points of attachment index for which the reliability and validity of the constructs were identified with good results, as in Robinson and Trail (2005) research, in which the points of attachment subscales had $\alpha$ from .75 to .85 and AVE .48 to .68 .

Sustainable transport intentions were measured with three items focused on intentions to adopt sustainable transport during the event. In comparison, past sustainable behaviours were assessed by three items that represented the behaviours linked to sustainable transportation. External constraints were measured by the lack of access, which was the only coherent factor in Trail and McCullough (2020) study. Internal constraints were measured by six items (i.e., lack of 
knowledge, lack of worth, lack of interest from others and lack of time). Although lack of time was an external constraint in Trail and McCullough's research (2020) and Trail's (2019) research, this factor was considered an internal constraint as a personal perception rather than an external imposition in the present investigation.

Following Trail and McCullough (2020), self-actualisation needs and the universalism values dimension were measured by three self-reported items with a 9-point scale based on Schwartz's (1992) value theory, with $-1=$ opposed to my needs/values, $0=$ not important, $3=$ important, $6=$ very important and $7=$ of supreme importance. Next, attitudes towards the campaign, points of attachment, sustainable transport intentions and internal and external constraints were measured with self-report items on a 7-point Likert-type scale, with $1=$ strongly disagree to $7=$ strongly agree. Finally, past sustainable behaviours were measured with two response formats: the number of times and percentage (Trail \& McCullough, 2020). Except for the items of self-actualisation needs, universalism values and past sustainable behaviours, all items appeared in random order. The demographic (age, gender, education level) and sport activity questions were at the end of the questionnaire.

Both an English and a Portuguese version of the questionnaire since the surfing event had an international context held in Portugal. The English version was based on Trail and McCullough (2020) original questionnaire. The Portuguese version was a translation of the former, produced by the authors and checked for cross-cultural equivalence by a professional translator using a committee approach (Brislin, 1980).

The ethical and deontological requirements inherent to scientific research were respected in the investigation's instruments and procedures.

\section{Procedures and data analysis}

Following the SSCEM (Trail \& McCullough, 2020), this study proposed nine hypotheses $\left(\mathrm{H}_{1}-\mathrm{H}_{8}\right)$ to identify which factors influence spectator sustainable transport intentions at international surfing events. Using IBM SPSS Statistics (v. 25), the normal distribution of the data was assessed through skewness (sk) and kurtosis (ku) measures. Absolute values of sk and ku lower than 3 and 7 , respectively, were the limits adopted to determine the possibility of using parametric tests, as they indicate non-severe violations of the normality assumption for parametric analysis (Kline, 2010; Marôco, 2014).

Considering the latent and observed variables in the model, structural equation modelling (SEM) analysis can examine multiple hypotheses and simultaneously deal with the errors in the measurement of the model. SEM was performed with the lavaan package (v. 0.6.4; Rosseel, 2012) from the R statistical package (v. 4.0.2 for Windows; R Core Team, 2020).

Since the statistical analysis did not reveal severe violations to the normal distribution, the maximum likelihood estimation with robust standard errors (MLR) estimator was selected for SEM. The robust MRL also performs well with large sample sizes and missing values, treated with the full information maximum likelihood (FIML) imputation. Goodness of fit of the model was assessed with robust fit measures, namely chi-square $(\chi 2)$, comparative fit index (CFI), TuckerLewis index (TLI), root mean square error of approximation (RMSEA), and the standardised root mean square residual (SRMR). Thresholds CFI $>0.900$, TLI $>0.900$, RMSEA $<0.080$ and SRMR $<0.08$ were indicative of good model fit (Hair et al., 2010; Marôco, 2014). Items that were not significant for a $\mathrm{p}<0.5$ or which presented problems during the fit of the model were removed.

The SemTools R package (v.0.5.3; Jorgensen et al., 2020) was used to estimate the composite reliability $(\mathrm{CR})$ through the coefficient omega $(\omega)$ for the first-order factors and the coefficient omega at Level $1\left(\omega_{\mathrm{L} 1}\right)$ for the points of attachment higher-order factor (Bollen, 1980; Fornell \& Larcker, 1981; Green \& Yang, 2009), adopting $\omega \geq 0.7$ reference values (Hair et al., 2010; Marôco, 2014) as indicative of acceptable internal consistency. 
The model's discriminant validity was assessed by calculating the heterotrait-monotrait (HTMT) ratio of correlations, which has proved to be a more sensitive method than the FornellLarcker criterion (Henseler et al., 2015). HTMT $_{.85}$ criterion was used, considering the threshold value HTMT $>.85$ to distinguish a lack of discriminant validity (Henseler et al., 2015).

Three hypotheses were formulated for spectator segmentation based on SSCEM's results $\left(\mathrm{H}_{9 a}\right.$ and $\left.\mathrm{H}_{9 b}\right)$ and the sociodemographic and sport activity characteristics $\left(\mathrm{H}_{10}\right)$. The cluster analysis used IBM SPSS Statistics (v. 25), and the procedure followed Mooi and Sarstedt (2011) orientations. The non-hierarchical K-means was the chosen method to compute the cluster analysis. The significant differences in the clusters for the model factors were evaluated with the KruskalWallis test followed by the multiple comparisons of means rank tests (Marôco, 2014). A higher mean rank corresponds to the tendency of higher values on the response scale. The sociodemographic differences between clusters were evaluated with Pearson's chi-square test. Statistically significant effects were those with $p<0.05$.

\section{Results}

The fit of the measurement model was good $\left(\chi 2_{(188)}=286.737 ; \mathrm{RMSEA}=.039 ; \mathrm{CFI}=.954 ; \mathrm{TLI}=\right.$ $.943 ;$ SRMR $=.049$ ).

The sk and ku measures attested to non-severe violations of the normality for all items except for past sustainable transport behaviour where $94.6 \%$ of the spectators never used a shuttle bus at surfing events. In addition, good internal consistency reliability and convergent validity were observed within most factors, except for attitudes and internal constraints, which presented values slightly below the recommended threshold (see Table 2).

The points of attachment showed good reliability, with $C R$ above the reliability criterion $\omega_{\mathrm{L} 1}>.70$.

Discriminant validity was confirmed for all factors since all $\mathrm{HTMT}_{.85}$ values were under the reference threshold (Table 3).

The goodness of fit of the structural model was acceptable $\left(\chi 2_{(259)}=417.053\right.$; RMSEA $=.043$; $\mathrm{CFI}=.928 ; \mathrm{TLI}=.917$; SRMR $=.062$ ). This investigation supported hypotheses $\mathrm{H}_{1}, \mathrm{H}_{5}, \mathrm{H}_{6}, \mathrm{H}_{7}$ and $\mathrm{H}_{8}$ (Figure 3) as it was found that there was a positive significant direct effect of (i) self-actualisation needs on universalism values, (ii) points of attachment on attitudes towards the campaign, (iii) past sustainable transport behaviours on sustainable transport intentions and a negative effect of (iv) internal constraints on attitudes towards the campaign and (v) external constraints on sustainable transport intentions. The results did not support hypotheses $\mathrm{H}_{2 a}, \mathrm{H}_{2 b}, \mathrm{H}_{3}$ or $\mathrm{H}_{4}$, i.e., the effects of self-actualisation needs and universalism values on attitudes towards the campaign were not supported and, consequently, the effect of self-actualisation needs on attitudes towards the campaign mediated by universalism values was also not confirmed. In addition, attitudes towards the campaign had a negative significant effect on sustainable transport intentions, contrary to the proposed significant positive effect.

Points of attachment were the only factor with a significant effect on attitudes towards the campaigns. However, the sustainable transport intentions accounted for a total effect $\beta=.130$, adding one more significant relationship.

The two-step cluster analysis identified three clusters regarding spectator sustainable transport intentions. With the number of clusters defined, the K-means cluster analysis classified (Figure 4).

i. The 'committed' to use sustainable transport, composed of more men (53.2\%), young people (67\% under 31 years old), with university attendance (78\%) and surfers (34\%).

ii. The 'undecided' to use sustainable transport, encompassing more women (54.2\%), young people (61\% under 31 years old), with university attendance (74.6\%), and surfers (38.6\%). 
Table 2. Items distributional properties (mean, standard deviation, skewness, and kurtosis) and loadings of items on constructs (standardized loadings and omega coefficient).

\begin{tabular}{|c|c|c|c|c|c|c|}
\hline & M & SD & sk & $\mathrm{Ku}$ & $\lambda$ & $\omega$ \\
\hline Self-actualisation needs & & & & & & .72 \\
\hline $\begin{array}{l}\text { Inner peace - At peace with one's self } \\
\text { and life. }\end{array}$ & 6.2 & 1.19 & -2.02 & 4.76 & .810 & \\
\hline $\begin{array}{l}\text { Aesthetic - Being appreciative of beautiful } \\
\text { things in life. }\end{array}$ & 6.0 & 1.20 & -1.78 & 3.39 & .740 & \\
\hline $\begin{array}{l}\text { Wisdom - Accumulated knowledge of life } \\
\text { gained through experience. }\end{array}$ & 6.2 & 1.04 & -1.69 & 2.70 & .450 & \\
\hline Universalism Values & & & & & & .69 \\
\hline $\begin{array}{l}\text { Environmentalism - Protecting the } \\
\text { environment. }\end{array}$ & 5.8 & 1.32 & -1.25 & .745 & .643 & \\
\hline $\begin{array}{l}\text { Social justice - Fair and dignified treatment of } \\
\text { all people within society. }\end{array}$ & 6.0 & 1.38 & -1.73 & 2.84 & 656 & \\
\hline $\begin{array}{l}\text { Tolerance - Accepting differing views of other } \\
\text { people and treating them fairly. }\end{array}$ & 5.2 & 1.64 & -.96 & .161 & 640 & \\
\hline Attitude towards the campaign & & & & & & .60 \\
\hline $\begin{array}{l}\text { I like that this event is trying to promote } \\
\text { people's environmentally } \\
\text { sustainable practices. }\end{array}$ & 6.4 & .88 & -2.01 & 4.91 & .681 & \\
\hline $\begin{array}{l}\text { I like that this event is inspiring people to be } \\
\text { more environmentally friendly. }\end{array}$ & 6.2 & 1.02 & -1.74 & 4.13 & .653 & \\
\hline Points of attachment & & & & & & .74 \\
\hline Attachment to the surfers & & & & & .919 & .79 \\
\hline $\begin{array}{l}\text { I am a fan of the surfers on the World Surf } \\
\text { League (WSL) events. }\end{array}$ & 5.1 & 1.68 & -.721 & -.285 & .875 & \\
\hline I am a big fan of specific surfers. & 4.3 & 1.84 & -.259 & -.955 & .760 & \\
\hline Attachment to the level of sport & & & -.642 & & .902 & .87 \\
\hline $\begin{array}{l}\text { I am a fan of WSL events regardless of who } \\
\text { is surfing. }\end{array}$ & 4.8 & 1.67 & & -.221 & .793 & \\
\hline $\begin{array}{l}\text { I consider myself a fan of WSL events, and } \\
\text { not just one specific surfer. }\end{array}$ & 4.8 & 1.67 & -.487 & -.466 & .789 & \\
\hline I am a big fan of WSL events. & 4.8 & 1.72 & -.543 & -.533 & .906 & \\
\hline Attachment to the community & & & & & .415 & .81 \\
\hline $\begin{array}{l}\text { I feel connected to numerous aspects of the } \\
\text { Peniche community. }\end{array}$ & 4.2 & 1.64 & -216 & -.527 & .821 & \\
\hline $\begin{array}{l}\text { I feel that I am a part of the } \\
\text { Peniche community. }\end{array}$ & 3.8 & 1.86 & 0.060 & -.967 & .822 & \\
\hline $\begin{array}{l}\text { I support the Peniche community as a whole. } \\
\text { Internal constraints }\end{array}$ & 5.3 & 1.35 & -.503 & -.136 & .604 & .66 \\
\hline $\begin{array}{l}\text { Lack of interest from others - My friends are } \\
\text { not interested in acting sustainably. }\end{array}$ & 2.4 & 1.66 & 1.159 & .399 & .577 & \\
\hline $\begin{array}{l}\text { Lack of interest from others - My family is not } \\
\text { interested in acting sustainably. }\end{array}$ & 2.5 & 1.81 & 1.005 &.-095 & .665 & \\
\hline $\begin{array}{l}\text { Lack of interest from others - My significant } \\
\text { other is not interested in acting sustainably }\end{array}$ & 2.4 & 1.45 & 1.067 & .385 & .529 & \\
\hline $\begin{array}{l}\text { Lack of worth - I don't think using sustainable } \\
\text { transportation is worthwhile. }\end{array}$ & 2.2 & 1.49 & 1.56 & 1.94 & .315 & \\
\hline $\begin{array}{l}\text { Lack of time - I don't have time to catch a } \\
\text { shuttle bus at surfing events. }\end{array}$ & 3.7 & 1.57 & -.031 & -.390 & .286 & \\
\hline $\begin{array}{l}\text { Lack of knowledge - I don't understand why } \\
\text { this event is worried about sustainable } \\
\text { transportation. }\end{array}$ & 2.0 & 1.48 & 1.771 & 2.601 & .415 & \\
\hline \multicolumn{7}{|l|}{ External constraints } \\
\hline $\begin{array}{l}\text { Lack of access - It is just easier to go to } \\
\text { surfing events by car than to catch a } \\
\text { shuttle bus. }\end{array}$ & 4.7 & 1.79 & -.634 & -.545 & & \\
\hline \multicolumn{7}{|l|}{ Past sustainable transport behaviours } \\
\hline $\begin{array}{l}\text { How many times have you used a shuttle bus } \\
\text { at surfing events? }\end{array}$ & 0 & .396 & 5.393 & 31.13 & & \\
\hline \multicolumn{7}{|l|}{ Sustainable transport intentions } \\
\hline $\begin{array}{l}\text { During this event, I intend to use sustainable } \\
\text { transportation. }\end{array}$ & 3.7 & 1.72 & .192 & -.810 & & \\
\hline
\end{tabular}


Table 3. Discriminant validity (HTMT below the diagonal).

\begin{tabular}{lllllll}
\hline & 1 & 2 & 3 & 4 & 5 & 6 \\
\hline 1.Needs & - & & & & & \\
2.Values & .61 & - & & & & \\
3.Attitudes & .37 & .24 & - & & & \\
4. Attachment to the surfers & .15 & .09 & .26 & - & & - \\
5. Attachment to the level of sport & .15 & .09 & .25 & .83 & - & .01 \\
6. Attachment to the community & .08 & .04 & .18 & .43 & .42 & -01 \\
7. Internal constraints & .23 & .13 & .52 & .01 & .01 & .01 \\
\hline
\end{tabular}

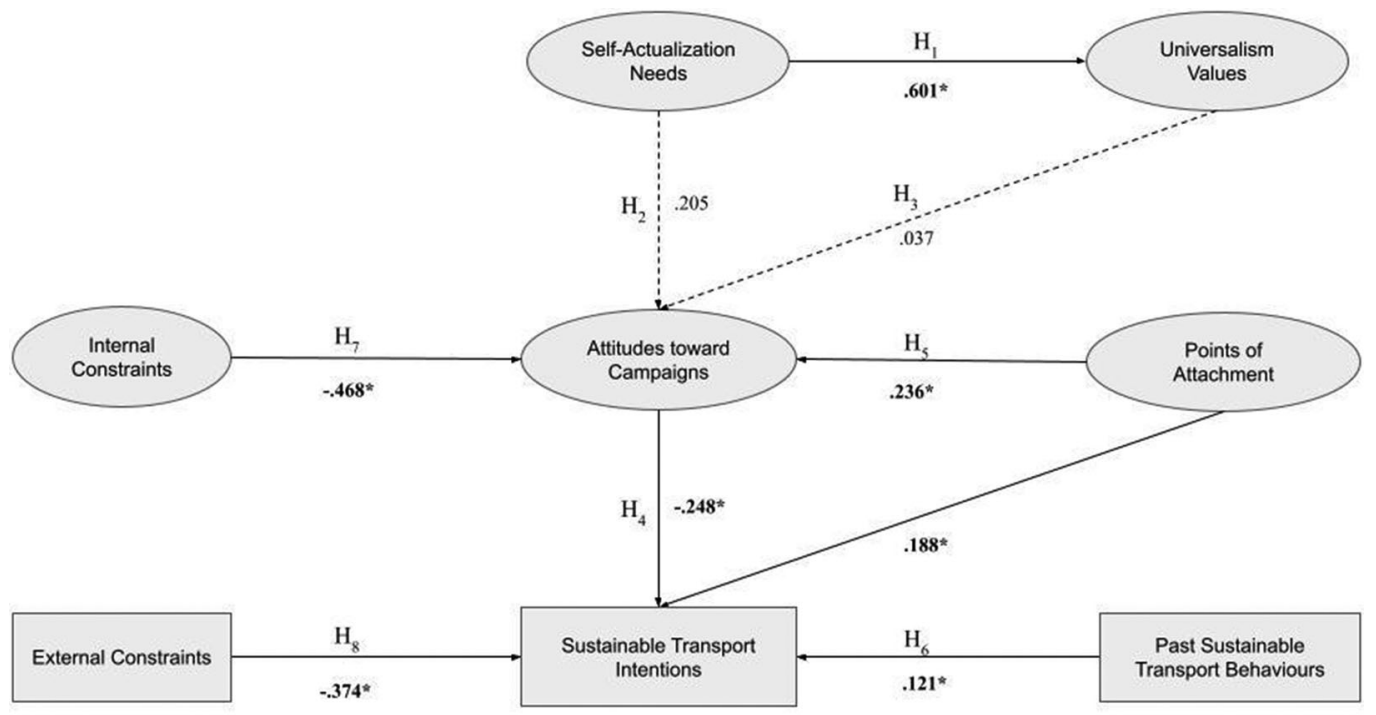

Legend: $\boldsymbol{\beta}^{*}$ significant for $p<.05$

Figure 3. Path coefficients in the sport sustainability campaign evaluation model $\left(R^{2}=.225\right)$.

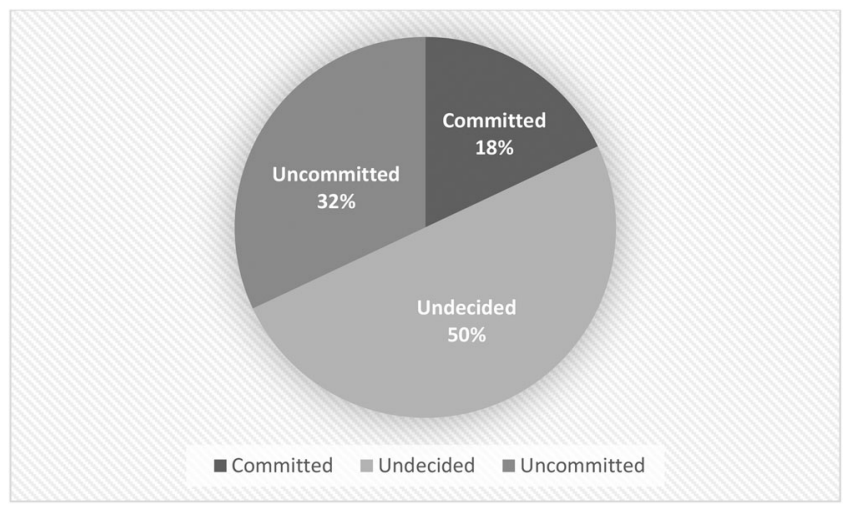

Figure 4. Spectator segments based on clusters analysis.

iii. The 'uncommitted' to use sustainable transport, combining more women (52.7\%), young people (70.6\% under 31 years old), with university attendance (77.8\%) and surfers (42\%).

A Kruskal-Wallis test revealed that only six items showed a significant difference between the clusters after testing all the items present in the model (Table 4), namely, aesthetic need, attachment to the community (two items), lack of time, lack of access, and past sustainable behaviour. 
Table 4. Kruskal-Wallis test and multiple comparisons of mean ranks for aesthetic need, attachment to the community, lack of time, lack of access and past sustainable behaviour between clusters.

\begin{tabular}{|c|c|c|c|c|c|c|}
\hline & \multirow[b]{2}{*}{ Kruskal-Wallis test } & \multicolumn{5}{|c|}{$\begin{array}{l}\text { Multiple Comparisons of Mean } \\
\text { ranks using LSD test }\end{array}$} \\
\hline & & (I) Cluster & (J) Cluster & $\begin{array}{c}\text { Mean } \\
\text { Difference (I-J) }\end{array}$ & S.E. & Sig. \\
\hline Aesthetic need & $\left(X_{K W}^{2}(2)=7.368 ; p=0.025 ; N=349\right)$ & "Committed" & "Undecided" & $(200.39-164.17)$ & 13.96 & .010 \\
\hline $\begin{array}{l}\text { Attachment to } \\
\text { the } \\
\text { community } \\
\text { (item1) }\end{array}$ & $\left(X_{K W}^{2}(2)=6.159 ; p=0.046 ; N=350\right)$ & "Committed" & "Uncommitted" & $(200.82-162.25)$ & 15.50 & .013 \\
\hline $\begin{array}{l}\text { Attachment to } \\
\text { the } \\
\text { community } \\
\text { (item2) }\end{array}$ & $\left(X_{K W}^{2}(2)=7.617 ; p=0.022 ; N=346\right)$ & "Committed" & "Uncommitted" & $(201.30-158.36)$ & 15.43 & .006 \\
\hline Lack of time & $\left(X_{K W}^{2}(2)=17.585 ; \mathrm{p}=0.00 ; \mathrm{N}=347\right)$ & $\begin{array}{l}\text { "Undecided" } \\
\text { "Uncommitted" }\end{array}$ & $\begin{array}{l}\text { "Committed" } \\
\text { "Committed" } \\
\text { "Undecided" }\end{array}$ & $\begin{array}{l}(173.81-137.69) \\
(201.80-137.69) \\
(201.80-173.81)\end{array}$ & $\begin{array}{l}13.99 \\
15.03 \\
11.52\end{array}$ & $\begin{array}{l}.010 \\
.000 \\
.016\end{array}$ \\
\hline Lack of access & $\left(X^{2}{ }_{K W}(2)=46.619 ; p=0.00 ; N=352\right)$ & "Uncommitted" & $\begin{array}{l}\text { "Committed" } \\
\text { "Undecided" }\end{array}$ & $\begin{array}{l}(230.60-138.74) \\
(230.60-158.98)\end{array}$ & $\begin{array}{l}14.79 \\
11.34\end{array}$ & $\begin{array}{l}.000 \\
.000\end{array}$ \\
\hline $\begin{array}{l}\text { Past } \\
\text { sustainable } \\
\text { behaviour }\end{array}$ & $\left(X_{K W}^{2}(2)=16.518 ; p=0.00 ; N=352\right)$ & "Committed" & $\begin{array}{l}\text { "Undecided" } \\
\text { "Uncommitted" }\end{array}$ & $\begin{array}{l}(196.67-173.47) \\
(196.67-174.91)\end{array}$ & $\begin{array}{l}5.77 \\
6.20\end{array}$ & $\begin{array}{l}.000 \\
.001\end{array}$ \\
\hline
\end{tabular}

Legend:mean difference is significant at the 0.05 level..

Focusing the analysis on the significant differences found between the clusters, a multiple comparison of mean ranks using Fisher's least significant difference (LSD) showed the 'committed' differed in the tendency to a greater appreciation of aesthetic need compared to the 'undecided'; in a greater identification with the community than the 'uncommitted'; and in having previously travelled by shuttle bus at surf events as compared to the other segments. On the other hand, the 'committed' tended to disagree with lack of time as a constraint on the use of sustainable transport in the surf event as compared to the others. The 'uncommitted' tended to agree on lack of access to sustainable transport in the surf event as a constraint compared to the remaining clusters.

Concerning the sociodemographic variables - gender $\left(X^{2}(2)=1.03 ; p=.598 ; N=351\right)$, age $\left(X^{2}(6)=4.894 ; p=.558 ; N=318\right)$, education level $\left(X^{2}(2)=2.15 ; p=.905 ; N=348\right)$ - and sport activity $\left(X^{2}(4)=2.139 ; p=.710 ; N=351\right)$, there was no significant difference between the three clusters in terms of their sustainable transport intentions.

The findings from the cluster analysis validated $\mathrm{H}_{9 a}$ since the needs, constraints, and past sustainable transport behaviours differentiated the clusters. However, $\mathrm{H}_{9 b}$ and $\mathrm{H}_{10}$ were not corroborated since values, sociodemographic and sport activity did not significantly differ between clusters.

\section{Discussion}

Given the importance of focusing events' environmental campaigns on reducing the environmental impact of transportation (Boggia et al., 2018; Chirieleison \& Scrucca, 2017), particularly on sporting events (Edwards et al., 2016, Cooper \& McCullough, 2021), this investigation studied spectator intentions to use sustainable transportation during an international surfing event. The findings revealed that spectators who are guided by self-actualisation needs are also guided by universal values. However, none of these factors influenced them to have a more positive attitude towards the use of sustainable transport during the surf event. Thus, these results do not support Trail and McCullough (2020) findings nor of the several studies advocating the positive influence of the holding of universal values, such as environmentalism, as predictors of greater 
awareness and environmental behaviour (Casper et al., 2017; de Groot \& Steg, 2010; Gau et al., 2019).

Focusing on needs and values as predictors of environmental attitude and behaviour, a study on recreational cyclists found that not only the environmental values and motivations influenced the choice of a more sustainable mode of transport, such as cycling, but also values such as happiness or self-esteem (Ho et al., 2015). In this investigation, the 'committed' spectators had a greater identification with aesthetic need than the 'undecided', although both largely considered it as an important need. As a result, sport event managers should promote the event's sustainable transportation to mitigate the unaesthetic issues of event transportation. The operationalisation of this strategy may include the displacement of parking close to the beach to more urban areas contiguous to the events while promoting the importance of using more environmentally sustainable transportation alternatives (e.g., shuttle busses) to ensure the conservation of the natural beauty of the beach and surrounding natural areas. Furthermore, surf event managers should also increase the use of sustainable transport through communication strategies that provide a direct link to the effective conservation of the natural space.

This study also found the association between positive attitudes towards the environmental campaign and lower intentions to use sustainable transport during the event. Again, this finding contradicts the SSCEM and other studies that have found the same effect on environmental behaviour in sport contexts (Kil et al., 2014; Lin \& Lee, 2020; McCullough, 2013). However, the attitude-behaviour gap has been highlighted in the adoption of sustainable transport in sport tourism (Martins et al., 2021; Mascarenhas et al., 2021), supported by this study's results. Furthermore, the additional time and effort required to adopt pro-environmental behaviours contribute to the inconsistency between attitude and environmental behaviours (e.g., sustainable transportation; Bilynets \& Cvelbar, 2020; Tobler et al., 2012 ). In the tourist context, understanding the environmental attitude-behaviour gap requires exploring how tourists justify the dissonance between their attitudes and the consequent environmental behaviours (Juvan \& Dolnicar, 2014).

Points of attachment (i.e., to the surfers, sport, level of the sport, community) predicted attitudes towards the campaign as in the SSCEM (Trail \& McCullough, 2020). Contributing to theoretical development, this study also found points of attachment as predictors of spectator sustainable transport intentions. Furthermore, the cluster analysis revealed that the 'committed' spectators felt more connected to the event's host community than the 'uncommitted' group. The connection to the community can be understood through the perspective of place attachment. The bond between sport practitioners and a specific place is a driver for environmental behaviour (Lin \& Lee, 2020; McCullough \& Kellison, 2016; Reineman \& Ardoin, 2018). In addition, sport event managers must consider strong ties with the event stakeholders (Le-Klähn \& Hall, 2015), such as strategic elements of the host community, to develop strategies and initiatives that promote sustainable transportation. From a more holistic approach, sport event managers should consider leveraging the host community's economic, social and environmental benefits to cultivate a stronger connection with the community, its culture, and stakeholders (O'Brien \& Chalip, 2008; Pereira et al., 2019). This approach is consistent with the governance of sustainable surfing tourism (Machado et al., 2018; Mach \& Ponting, 2018). Initiatives that enhance sustainable transportation at events (i.e., travel to and at the destination) include shuttle bus service to reduce carbon emissions and provide social advantages by decreasing traffic congestion, parking confusion and excessive noise (Chirieleison et al., 2020). Sustainable transport can also be developed through a "locavist" approach (Hollenhorst et al., 2014, p. 315), including low carbon models proposing short distances, low carbon modes of transport, and local capital investment. A guest ticket concept (Gronau, 2017), in which the tourists are allowed to use local public transport by paying a symbolic fee for accommodations or restaurants and food and beverage shops to subsidise local public transportation is an effective strategy for surfing events. 
The positive effect of the present study between the use of a shuttle bus service in past surfing events, and the intention to use sustainable transport during an event, corroborates the literature on past sustainable behaviours as a predictor of environmental action (Han, 2021). Notwithstanding, the spectators' mean responses confirmed that they never used a shuttle bus service at surfing events before, inferring the need to leverage such experiences; for example, surfing event spectators using shuttle bus could get discounts at local shops or other local events, leveraging sustainable transport and interaction with the community.

Finally, the internal and external constraint factors were negatively related to spectator sustainable transport intentions. The internal perception of lack of time had less influence on the 'committed' spectators than other segments. Conversely, the external constraint of lack of access had more impact on the 'uncommitted' spectators. Besides these differences, the spectators' mean responses agreed with the lack of access to catch the shuttle bus. This finding stresses the convenience of using the private car in a tourism setting (Doran et al., 2017; Juvan \& Dolnicar, 2014; Schlemmer et al., 2019) like sporting events (Malhado \& Rothfuss, 2013).

Furthermore, the availability of information on transport services is an attractive factor for transport usage (Ceder \& Perera, 2014; Collins \& Potoglou, 2019; Malhado \& Rothfuss, 2013). Thus, having information available in the media (e.g., event webpage and social media) about the shuttle bus service with an evident meeting point characteristic that advances the logo spot sign, the vehicle colour, the logo and a real-time actualisation schedule could be a strategic management option to consider. Following the same line of action, alternative and sustainable modes of transportation at destinations should be frequent and have extended hours to encourage further adoption (Le-Klähn \& Hall, 2015; Scuttari et al., 2019).

Sport event managers should also ponder the communication of their sustainable transport campaigns focused on market segments using persuasive communication which incorporates visual information (Martin et al., 2017; Tölkes, 2018). For example, images depicting pristine beaches and peaceful Peniche village with shuttle busses could appeal to the spectators' aesthetic need. Also, role models (i.e., points of attachment) have been evidenced as a strategy to promote sustainable transport (Hanna et al., 2018). In order to foster extensive use of the shuttle bus at surfing events, the sustainable transport campaigns could feature notable surfers as another point of attachment.

It should be noted the absence of the influence of sociodemographic variables on sustainable transport intentions. This result supports Prillwitz and Barr (2011) findings, which envisaged the difficulty of using environmental behaviour based on sociodemographic characteristics due to the specificity of leisure travel decisions compared to the daily mobility style. Regarding sport activity, the results also suggested a lack of distinction between surfers and non-surfers among spectators, allowing the design of more generalist strategies to foster the use of sustainable transport at surfing events.

The methodological implications of this study comprise the validation of the SSCEM as an appropriate resource to investigate spectator responses to sustainable transport campaigns in the context of nature-based sporting events. Nevertheless, the measurement of just one type of value/need may have limited the study. Further, the absence of some variables in adopting sustainable transport (e.g., accessibility to the location/origin of the spectators) limit our findings. Therefore, in future studies, items must be selected to correspond to the specific sport context under study (e.g., the needs and values that best portray the sport subculture; Ford \& Brown, 2005; Green, 2001 ). Additionally, future investigations should examine spectators' attachment to the local community and identify the specific factors that facilitate a spectator's connection to the community. Also, the effect of accessibility to the event site, the frequency of the transport service and the quality of the infrastructure as external constraints on choosing more sustainable means of transport for the event and during the event should be assessed (Collins \& Potoglou, 2019; Malhado \& Rothfuss, 2013). Finally, although it is challenging to predict tourists' environmental behaviours, based on sociodemographic variables (Prillwitz \& Barr, 2011), the spectators' 
origin may be relevant to their segmentation since there is evidence that non-local residents are more likely to use sustainable modes of transportation compared to residents (Shiftan et al., 2006).

Since this research only studied attitudes and intentions, and the gap between attitudes/ intentions and behaviour is recognised in the literature, such as changing the means of transport (Bilynets \& Cvelbar, 2020), future studies should investigate spectator behaviours to provide deeper knowledge of sustainable transport behaviours. In addition, the questionnaire only contained closed-ended questions. This type of data collection can produce biased responses that influence the results (McKercher \& Prideaux, 2011). Therefore, it is recommended that future studies include qualitative approaches to address sustainable transportation at sport events.

\section{Conclusion}

In conclusion, this investigation identified several factors that must be analysed to attend to the implementation of sustainable transport campaigns in surfing events and provided insight into the distinctive characteristics of the spectators according to their sustainable transport intentions. It also deepened knowledge concerning international surf tourism events which can inform other international sport events.

The study's findings illustrate the need to mitigate spectators' constraints (i.e., lack of time, facilitate access to sustainable modes of transport during the event) and focus on the spectators' connection to the community (i.e., point of attachment). For these purposes, sport event managers should use a low carbon local approach with the participation of the various event stakeholders, including the local community. Further campaigns should inform spectators of conditions and ways to access sustainable modes of transportation during the event. In addition, targeted environmental communications for sustainable transport initiatives should be designed for each spectator segment.

To study the sustainable intentions of sport event spectators, the application of SSCEM requires consideration of the values and needs being measured. Additionally, the spectators' segmentation must also be replicated in future research since there is an urgent need for the effective implementation of sustainable transport in the context of sporting events. Thus, it is vital to strengthen campaigns and strategies that aim for behavioural change.

Finally, this study contributed to theoretical development by adding a significant relationship to the SSCEM (i.e., the direct effect of points of attachment on sustainable transport intentions). Also, this investigation increased scientific knowledge in sport management, primarily by addressing the topic of environmental sustainability of transportation at events, which is of paramount importance in helping to mitigate the carbon footprint of sport tourism events.

\section{Disclosure statement}

No potential conflict of interest was reported by the authors.

\section{Funding}

This work was supported by National Funds provided by FCT- Foundation for Science and Technology under the project UIDB/04020/2020.

\section{Notes on contributors}

Rute Martins, ongoing PhD at the University of Lisbon. Her research interests are sports' environmental sustainability, sports events, and outdoor sport tourism. 
Elsa Pereira, PhD in Sport Sciences, is a professor at the University of Algarve. Her research interests are situated in the field of Sport Sciences, namely sport management, sport strategy and sustainable development, sport events, sports tourism, and nautical tourism.

António Rosado, PhD, is a full professor at Lisbon University. His research interests are situated in the fields of social psychology and human development.

Brian P. McCullough, PhD in Kinesiology, is an Associate Professor at Texas A\&M University. His research interests focus on sport ecology, the bidirectional relationship between sport and the natural environment.

Margarida Mascarenhas, PhD in Sport Sciences, is a professor at the University of Lisbon. Her research interests are situated in the field of Sport Management, namely sport's environmental sustainability, sport tourism, sport events, sport finance and economics, and sport strategy.

\section{ORCID}

Rute Martins (iD http://orcid.org/0000-0003-1080-2974

Elsa Pereira (iD http://orcid.org/0000-0002-5314-648X

António Rosado (D) http://orcid.org/0000-0003-2336-0853

Brian McCullough iD http://orcid.org/0000-0002-9085-7926

Margarida Mascarenhas (iD http://orcid.org/0000-0001-8982-3211

\section{References}

Ajzen, I., \& Madden, T. J. (1986). Prediction of goal-directed behavior: Attitudes, intentions, and perceived behavioral control. Journal of Experimental Social Psychology, 22(5), 453-474. https://doi.org/10.1016/00221031(86)90045-4

Antolín, G., Alonso, B., Cordera, R., \& dell'Olio, L. (2019). The effect of introducing parking policies on managing mobility to beaches in touristic coastal towns. Sustainability, 11(13), 3528. https://doi.org/10.3390/su11133528

Bacharach, S. B. (1989). Organizational theories: Some criteria for evaluation. The Academy of Management Review, 14(4), 496-515. https://doi.org/10.2307/258555

Ballouli, K., Trail, G., Koesters, T., \& Bernthal, M. (2016). Differential effects of motives and points of attachment on conative loyalty of formula 1 U.S. grand prix attendees. Sport Marketing Quarterly, 25(3), 166-181.

Barrett, M., Bunds, K., Casper, J., \& Edwards, M. (2019). A descriptive analysis of corporate environmental responsibility in major league professional sport. Journal of Applied Sport Management, 11(3), 35-46. https://doi.org/10. 18666/JASM-2019-V11-13-9509

Bilynets, I., \& Cvelbar, L. K. (2020). Past, present and future of the research on the pro-environmental behaviour in tourism: A bibliometric analysis. Economic and Business Review for Review, 22(2), 289-312. https://doi.org/10. 15458/ebr102

Boggia, A., Massei, G., Paolotti, L., Rocchi, L., \& Schiavi, F. (2018). A model for measuring the environmental sustainability of events. Journal of Environmental Management, 206, 836-845. https://doi.org/10.1016/j.jenvman.2017.11. 057

Bollen, K. A. (1980). Issues in the comparative measurement of political democracy. American Sociological Review, 45(3), 370-390. https://doi.org/10.2307/2095172

Brislin, R. W. (1980). Translation and content analysis of oral and written material. In. J. W. Berry \& H. C. Triandis (Ed.), Handbook of cross-cultural psychology: Methodology. (pp. 389-444). Allyn and Bacon.

Casper, J., McCullough, B. P., \& Pfahl, M. E. (2020). Examining environmental fan engagement initiatives through values and norms with intercollegiate sport fans. Sport Management Review, 23(2), 348-360. https://doi.org/10.1016/ j.smr.2019.03.005

Casper, J., Pfahl, M., \& McCullough, B. (2017). Is going green worth it? Assessing fan engagement and perceptions of athletic department environmental efforts. Journal of Applied Sport Management, 9(1), 106-129. https://doi. org/10.18666/JASM-2017-V9-I1-7690

Casper, J., Pfahl, M., \& McCullough, B. P. (2014). Intercollegiate sport and the environment: Examining fan engagement based on athletics department sustainability efforts. Journal of Issues in Intercollegiate Athletics, 7, 65-91.

Ceder, A., \& Perera, S. (2014). Detecting and improving public-transit connectivity with case studies of two world sport events. Transport Policy, 33, 96-109. https://doi.org/10.1016/j.tranpol.2014.03.001

Chen, X., Niu, J., Ken', N. A., Nakagami, C., Zhang, Q., Qian, X., \& Nakajima, J. (2018). Green sports supporting a lowcarbon society: Inspiration from Japan. International Journal of Global Warming, 14(1), 61-80. https://doi.org/doi: https://doi.org/10.1504/JGW.2018.088645 
Chirieleison, C., Montrone, A., \& Scrucca, L. (2020). Event sustainability and sustainable transportation: A positive reciprocal influence. Journal of Sustainable Tourism, 28(2), 240-262. https://doi.org/10.1080/09669582.2019. 1607361

Chirieleison, C., \& Scrucca, L. (2017). Event sustainability and transportation policy: A model-based cluster analysis for a cross-comparison of hallmark events. Tourism Management Perspectives, 24, 72-85. https://doi.org/10.1016/j. tmp.2017.07.020

Choi, J. S. A. (2016). Going green in baseball - a case study of the SK Wyverns. International Journal of Sports Marketing and Sponsorship, 17(4), 368-379. https://doi.org/10.1108/IJSMS-11-2016-022

Collins, A., \& Potoglou, D. (2019). Factors influencing visitor travel to festivals: Challenges in encouraging sustainable travel. Journal of Sustainable Tourism, 27(5), 668-688. https://doi.org/10.1080/09669582.2019.1604718

Cooper, J. A., \& McCullough, B. P. (2021). Bracketing sustainability: Carbon footprinting March Madness to rethink sustainable tourism approaches and measurements. Journal of Cleaner Production, 318(10), 128475-128416. https://doi.org/10.1016/j.jclepro.2021.128475

de Groot, J. I. M., \& Steg, L. (2010). Relationships between value orientations, self-determined motivational types and pro-environmental behavioural intentions. Journal of Environmental Psychology, 30(4), 368-378. https://doi. org/10.1016/j.jenvp.2010.04.002

Dolf, M., \& Teehan, P. (2015). Reducing the carbon footprint of spectator and team travel at the University of British Columbia's varsity sports events. Sport Management Review, 18(2), 244-255. https://doi.org/10.1016/j.smr.2014.06. 003

Dolnicar, S., Grun, B., \& Friedrich, L. (2018). Market segmentation analysis - understanding it, Doing it and making it useful. Springer Open.

Doran, R., Hanss, D., \& Larsen, S. (2017). Intentions to make sustainable tourism choices: Do value orientations, time perspective, and efficacy beliefs explain individual differences? Scandinavian Journal of Hospitality and Tourism, 17(3), 223-238. https://doi.org/10.1080/15022250.2016.1179129

Edwards, L., Knight, J., Handler, R., Abraham, J., \& Blowers, P. (2016). The methodology and results of using life cycle assessment to measure and reduce the greenhouse gas emissions footprint of "Major Events" at the University of Arizona. The International Journal of Life Cycle Assessment, 21(4), 536-554. https://doi.org/10.1007/s11367-0161038-4

Enders, C. K. (2010). Applied missing data analysis. Guilford Press.

Ford, N. J., \& Brown, D. (2005). Surfing and social theory: Experience, embodiment and narrative of the dream glide (1st ed.). Routledge. https://doi.org/10.4324/9780203415023

Fornell, C., \& Larcker, D. F. (1981). Evaluating structural equation models with unobservable variables and measurement error. Journal of Marketing Research, 18(1), 39-50. https://doi.org/10.2307/3151312

Frank, F., Pintassilgo, P., \& Pinto, P. (2015). Environmental awareness of surf tourists: A case study in the Algarve. Journal of Spatial and Organizational Dynamics, 3(2), 102-113.

Friedl, B., \& Steininger, K. W. (2002). Environmentally sustainable transport: Definition and long-term economic impacts for Austria. Empirica, 29(2), 163-180. https://doi.org/10.1023/A:1015600911243

Gau, L. S., Huang, J. C., Chen, M. I., \& Naylor, M. (2019). Team social responsibility embedded in correlates of universalism values, sport involvement, and team identification for sustainable management in sporting settings. Sustainability, 11(19), 5416. https://doi.org/10.3390/su11195416

González, R. M., Román, C., \& Ortúzar, J. d D. (2019). Preferences for sustainable mobility in natural areas: The case of Teide National Park. Journal of Transport Geography, 76, 42-51. https://doi.org/10.1016/j.jtrangeo.2019.03.002

Green, B. (2001). Leveraging subculture and identity to promote sport events. Sport Management Review, 4(1), 1-19. https://doi.org/10.1016/S1441-3523(01)70067-8

Green, S. B., \& Yang, Y. (2009). Reliability of summed item scores using structural equation modeling: An alternative to coefficient alpha. Psychometrika, 74(1), 155-167. https://doi.org/10.1007/s11336-008-9099-3

Gronau, W. (2017). Encouraging behavioural change towards sustainable tourism: A German approach to free public transport for tourists. Journal of Sustainable Tourism, 25(2), 265-275. https://doi.org/10.1080/09669582.2016. 1198357

Hair, J. F., Jr., Black, W. C., Babin, B. J., \& Anderson, R. E. (2010). Multivariate data analysis: A global perspective (7th ed.). Pearson Education.

Han, H. (2021). Consumer behavior and environmental sustainability in tourism and hospitality: A review of theories, concepts, and latest research. Journal of Sustainable Tourism, 29(7), 1021-1042. https://doi.org/doi: https:// doi.org/10.1080/09669582.2021.1903019

Hanna, P., Kantenbacher, J., Cohen, S., \& Gössling, S. (2018). Role model advocacy for sustainable transport. Transportation Research Part D: Transport and Environment, 61, 373-382. https://doi.org/10.1016/j.trd.2017.07.028

Henseler, J., Ringle, C. M., \& Sarstedt, M. (2015). A new criterion for assessing discriminant validity in variance-based structural equation modelling. Journal of the Academy of Marketing Science, 43(1), 115-135. https://doi.org/10. 1007/s11747-014-0403-8 
Hibbert, J. F., Dickinson, J. E., Gössling, S., \& Curtin, S. (2013). Identity and tourism mobility: An exploration of the attitude-behaviour gap. Journal of Sustainable Tourism, 21(7), 999-1016. https://doi.org/10.1080/09669582.2013. 826232

Hinch, T. D., \& Higham, J. E. S. (2001). Sport tourism: A framework for research. International Journal of Tourism Research, 3(1), 45-58. https://doi.org/10.1002/1522-1970(200101/02)3:1 < 45::AID-JTR243 > 3.0.CO;2-A

Ho, C. I., Liao, T. Y., Huang, S. C., \& Chen, H. M. (2015). Beyond environmental concerns: Using means-end chains to explore the personal psychological values and motivations of leisure/recreational cyclists. Journal of Sustainable Tourism, 23(2), 234-254. https://doi.org/10.1080/09669582.2014.943762

Hollenhorst, S. J., Houge-Mackenzie, S., \& Ostergren, D. M. (2014). The trouble with tourism. Tourism Recreation Research, 39(3), 305-319. https://doi.org/10.1080/02508281.2014.11087003

International Olympic Committee. (2012). Sustainability through sport-implementing the Olympic Movement's Agenda 21. https://stillmed.olympic.org/Documents/Commissions_PDFfiles/SportAndEnvironment/Sustainability_Through_ Sport.pdf

Jorgensen, T. D., Pornprasertmanit, S., Schoemann, A. M., \& Rosseel, Y. (2020). semTools: Useful tools for structural equation modeling. $R$ package version $0.5-3$. https://CRAN.R-project.org/package $=$ semTools

Juvan, E., \& Dolnicar, S. (2014). The attitude-behaviour gap in sustainable tourism. Annals of Tourism Research, 48, 76-95. https://doi.org/10.1016/j.annals.2014.05.012

Kil, N., Holland, S. M., \& Stein, T. V. (2014). Structural relationships between environmental attitudes, recreation motivations, and environmentally responsible behaviors. Journal of Outdoor Recreation and Tourism, 7-8, 16-25. https://doi.org/10.1016/j.jort.2014.09.010

Kim, Y., \& Trail, G. (2010). Constraints and motivators: A new model to explain sport consumer behavior. Journal of Sport Management, 24(2), 190-210. https://doi.org/10.1123/jsm.24.2.190

Kline, R. (2010). Principles and practice of structural equation modelling (3rd ed.). Guilford Press.

Klöckner, C. A. (2015). Target group segmentation - Why knowing your audience is important. In The psychology of pro-environmental communication: Beyond standard information strategies (pp. 146-160). Palgrave Macmillan. https://doi.org/10.1057/9781137348326

Kotler, P., Bowen, J. T., \& Makens, J. C. (2006). Marketing for hospitality and tourism (4th ed.). Prentice-Hall.

Larson, L. R., Usher, L. E., \& Chapmon, T. (2018). Surfers as environmental stewards: Understanding place-protecting behavior at Cape Hatteras National Seashore. Leisure Sciences, 40(5), 442-465. https://doi.org/10.1080/01490400. 2017.1305306

Le-Klähn, D.-T., \& Hall, C. M. (2015). Tourist use of public transport at destinations - a review. Current Issues in Tourism, 18(8), 785-803. https://doi.org/doi: https://doi.org/10.1080/13683500.2014.948812

Lin, Y. H., \& Lee, T. H. (2020). How do recreation experiences affect visitors' environmentally responsible behavior? Evidence from recreationists visiting ancient trails in Taiwan. Journal of Sustainable Tourism, 28(5), 705-726. https://doi.org/10.1080/09669582.2019.1701679

Mach, L., \& Ponting, J. (2018). Governmentality and surf tourism destination governance. Journal of Sustainable Tourism, 26(11), 1845-1862. https://doi.org/10.1080/09669582.2018.1513008

Machado, V., Carrasco, P., Contreiras, J. P., Duarte, A. P., \& Gouveia, D. (2018). Governing locally for sustainability: public and private organizations' perspective in surf tourism at Aljezur, Costa Vicentina, Portugal. Tourism Planning \& Development, 15(6), 692-704. https://doi.org/10.1080/21568316.2017.1415958

Malhado, A. C. M., \& Rothfuss, R. (2013). Transporting 2014 FIFA World Cup to sustainability: Exploring residents' and tourists' attitudes and behaviours. Journal of Policy Research in Tourism, Leisure and Events, 5(3), $252-269$. https://doi.org/10.1080/19407963.2013.801159

Marôco, J. (2014). Análise de equações estruturais: Fundamentos teóricos, software \& aplicações. Pêro Pinheiro. Report Number, Lda.

Martin, V. Y., Weiler, B., Reis, A., Dimmock, K., \& Scherrer, P. (2017). Doing the right thing': How social science can help foster pro-environmental behaviour change in marine protected areas. Marine Policy, 81, 236-246. https:// doi.org/10.1016/j.marpol.2017.04.001

Martins, R., Pereira, E., Rosado, A., \& Mascarenhas, M. (2021). Exploring the relationship between sport demand's key players and environmental sustainability: Pointers from a systematic review. Journal of Outdoor Recreation and Tourism, 35, 100419. https://doi.org/10.1016/j.jort.2021.100419

Mascarenhas, M., Pereira, E., Rosado, A., \& Martins, R. (2021). How has science highlighted sports tourism in recent investigation on sports' environmental sustainability? A systematic review. Journal of Sport \& Tourism, 25(1), 42-65. https://doi.org/doi: https://doi.org/10.1080/14775085.2021.1883461

McCullough, B. P. (2013). Identifying the influences on sport spectator recycling behaviours using the theory of planned behaviour. International Journal of Sport Management and Marketing, 14(1-4), 146-168. https://doi.org/ 10.1504/IJSMM.2013.060631

McCullough, B. P., \& Cunningham, G. (2011). Recycling intentions among youth baseball spectators. International Journal of Sport Management and Marketing, 10(1-2), 104. https://doi.org/10.1504/IJSMM.2011.043618

McCullough, B. P., \& Kellison, T. B. (2016, February). Go green for the home team: Sense of place and environmental sustainability in sport. Journal of Sustainability Education, 11, 1-14. 
McCullough, B. P., Orr, M., \& Watanabe, N. M. (2020). Measuring externalities: The imperative next step to sustainability assessment in sport. Journal of Sport Management, 34(5), 393-402. https://doi.org/10.1123/jsm.2019-0254

McCullough, B. P., Pfahl, M., \& Nguyen, S. (2016). The green waves of environmental sustainability in sport. Sport in Society, 19(7), 1040-1065. https://doi.org/10.1080/17430437.2015.1096251

McKercher, B., \& Prideaux, B. (2011). Are tourism impacts low on personal environmental agendas? Journal of Sustainable Tourism, 19(3), 325-345. https://doi.org/10.1080/09669582.2010.524702

Meng, B., \& Choi, K. (2016). Extending the theory of planned behaviour: Testing the effects of authentic perception and environmental concerns on the slow-tourist decision-making process. Current Issues in Tourism, 19(6), 528-544. https://doi.org/doi: https://doi.org/10.1080/13683500.2015.1020773

Mooi, E., \& Sarstedt, M. (2011). A concise guide to market research: The process, data, and methods using IBM SPSS statistics. Springer-Verlag. https://doi.org/doi:10.1007/978-3-642-12541-6

O'Brien, D., \& Chalip, L. (2008). Sport events and strategic leveraging: Pushing towards the triple bottom line. In A. G. Woodside \& D. Martin (Ed.), Tourism management: Analysis, behaviour and strategy (pp. 318-338). CAB International. https://doi.org/10.1079/9781845933234.0318

Peattie, K., \& Belz, F.-M. (2010). Sustainability marketing - An innovative conception of marketing. Marketing Review St. Gallen, 27(5), 8-15. https://doi.org/10.1007/s11621-010-0085-7

Peeters, P., Higham, J., Cohen, S., Eijgelaar, E., \& Gössling, S. (2019). Desirable tourism transport futures. Journal of Sustainable Tourism, 27(2), 173-188. https://doi.org/doi: https://doi.org/10.1080/09669582.2018.1477785

Pereira, R. P. T., Filimonau, V., \& Ribeiro, G. M. (2019). Score a goal for climate: Assessing the carbon footprint of travel patterns of the English Premier League clubs. Journal of Cleaner Production, 227, 167-177. https://doi.org/ 10.1016/j.jclepro.2019.04.138

Pereira, E., Mascarenhas, M., Flores, A., Chalip, L., \& Pires, G. (2020). Strategic leveraging: Evidences of small-scale sport events. International Journal of Event and Festival Management, 11(1), 69-88. https://doi.org/10.1108/IJEFM07-2018-0046

Portugal Tourism Board. (2017). Estratégia Turismo 2027. http://www.turismodeportugal.pt/SiteCollectionDocuments/ estrategia/estrategia-turismo-2027.pdf

Prillwitz, J., \& Barr, S. (2011). Moving towards sustainability? Mobility styles, attitudes and individual travel behaviour. Journal of Transport Geography, 19(6), 1590-1600. https://doi.org/10.1016/j.jtrangeo.2011.06.011

R Core Team. (2020). R: A language and environment for statistical computing. https://www.R-project.org/.

Reineman, D. R., \& Ardoin, N. M. (2018). Sustainable tourism and the management of nearshore coastal places: Place attachment and disruption to surf-spots. Journal of Sustainable Tourism, 26(2), 325-340. https://doi.org/10. 1080/09669582.2017.1352590

Robinson, M. J., \& Trail, G. T. (2005). Relationships among spectator gender, motives, points of attachment, and sport preference. Journal of Sport Management, 19(1), 58-80. https://doi.org/10.1123/jsm.19.1.58

Rocha, C., \& Fleury, F. (2017). Attendance of Brazilian soccer games: The role of constraints and team identification. European Sport Management Quarterly, 17(4), 485-505. https://doi.org/10.1080/16184742.2017.1306871

Rosseel, Y. (2012). Lavaan: An R package for structural equation modeling. Journal of Statistical Software, $48(2), 36$. https://doi.org/10.18637/jss.v048.i02

Saayman, M., Krugell, W., \& Saayman, A. (2016). Characterisation of cyclists' willingness to pay for green initiatives at Africa's largest cycle tour. South African Journal of Economic and Management Sciences, 19(3), 432-447. https:// doi.org/10.17159/2222-3436/2016/v19n3a9

Schlemmer, P., Blank, C., Bursa, B., Mailer, M., \& Schnitzer, M. (2019). Does health-oriented tourism contribute to sustainable mobility? Sustainability, 11(9), 2633. https://doi.org/10.3390/su11092633

Schwartz, S. H. (1992). Universals in the content and structure of values: Theoretical advances and empirical tests in 20 countries. In M. P. Zanna (Ed.), Advances in experimental social psychology (Vol. 25, pp. 1-65). Academic Press.

Scrucca, F., Severi, C., Galvan, N., \& Brunori, A. (2016). A new method to assess the sustainability performance of events: Application to the 2014 World Orienteering Championship. Environmental Impact Assessment Review, 56, 1-11. https://doi.org/10.1016/j.eiar.2015.08.002

Scuttari, A., Orsi, F., \& Bassani, R. (2019). Assessing the tourism-traffic paradox in mountain destinations. A stated preference survey on the Dolomites' passes (Italy). Journal of Sustainable Tourism, 27(2), 241-257. https://doi. org/doi: https://doi.org/10.1080/09669582.2018.1428336

Shiftan, Y., Vary, D., \& Geyer, D. (2006). Demand for park shuttle services--a stated-preference approach. Journal of Transport Geography, 14(1), 52-59. https://doi.org/10.1016/j.jtrangeo.2004.12.005

Stern, P. C., Dietz, T., Abel, T. D., Guagnano, G., \& Kalof, L. (1999). A value-belief-norm theory of support for social movements: The case of environmentalism. Human Ecology Review, 6(2), 81-97.

STOKE. (2020). Peniche. https://www.stokecertified.com/members/peniche/

Stryker, S., \& Burke, P. J. (2000). The past, present, and future of an identity theory. Social Psychology Quarterly, 63(4), 284-297. https://doi.org/10.2307/2695840

Teixeira, A. G. (2017). The sustainability of surfing tourism destinations: A case study of Peniche, Portugal [Master Thesis]. Escola Superior de Turismo e Tecnologia do Mar http://hdl.handle.net/10400.8/2719 
Tobler, C., Visschers, V. H. M., \& Siegrist, M. (2012). Addressing climate change: Determinants of consumers' willingness to act and to support policy measures. Journal of Environmental Psychology, 32(3), 197-207. https://doi.org/ 10.1016/j.jenvp.2012.02.001

Tölkes, C. (2018). Sustainability communication in tourism - A literature review. Tourism Management Perspectives, 27, 10-21. https://doi.org/10.1016/j.tmp.2018.04.00 https://doi.org/10.1016/j.tmp.2018.04.002

Trail, G. T. (2016). Marketing sustainability through sport. Sport Consumer Research Consultants LLC.

Trail, G. T. (2019). Sport consumer behavior (4th ed.). Sport Consumer Research Consultants LLC.

Trail, G., Anderson, D., \& Fink, J. (2005). Consumer satisfaction and identity theory: A model of sport spectator conative loyalty. Sport Marketing Quarterly, 14(2), 98-111.

Trail, G. T., \& McCullough, B. P. (2020). Marketing sustainability through sport: Testing the sport sustainability campaign evaluation model. European Sport Management Quarterly, 20(2), 109-129. https://doi.org/10.1080/ 16184742.2019.1580301

Trail, G. T., \& McCullough, B. P. (2021). A longitudinal study of sustainability attitudes, intentions, and behaviors. Sustainability Science, 16(5), 1503-1516. https://doi.org/10.1007/s11625-021-00954-7

Trail, G., \& McCullough, B. P. (2018). Differential effects of internal and external constraints on sustainability intentions: A hierarchical regression analysis by market segment of running event participants. Journal of Management for Global Sustainability, 6(2), 1-30. https://doi.org/10.13185/JM2018.06206

Triantafyllidis, S., Ries, R. J., \& Kaplanidou, K. (2018). Carbon dioxide emissions of spectators' transportation in collegiate sporting events: Comparing on-campus and off-campus stadium locations. Sustainability, 10(1), 241. https:// doi.org/10.3390/su10010241

United Nations Environment Programme. (2019). COP25 - transforming tourism for climate action. https://www.unenvironment.org/events/conference/cop25-transforming-tourism-climate-action

United Nations Framework Convention on Climate Change. (2018). Sports for climate action framework - version 02.0: United Nations Framework Convention on Climate Change. https://unfccc.int/sites/default/files/resource/ Sports_for_Climate_Action_Declaration_and_Framework_0.pdf

Wheaton, B. (2007). Identity, politics, and the beach: Environmental activism in surfers against sewage. Leisure Studies, 26(3), 279-302. https://doi.org/10.1080/02614360601053533

Wheaton, B. (2010). Introducing the consumption and representation of lifestyle sports. Sport in Society, 13(7-8), 1057-1081. https://doi.org/10.1080/17430431003779965

Whetten, D. A. (1989). What constitutes a theoretical contribution? Academy of Management Review, 14(4), 490-495. https://doi.org/10.5465/amr.1989.4308371

Whitmarsh, L., \& O'Neill, S. (2010). Green identity, green living? The role of pro-environmental self-identity in determining consistency across diverse pro-environmental behaviours. Journal of Environmental Psychology, 30(3), 305-314. https://doi.org/10.1016/j.jenvp.2010.01.003

Wicker, P. (2018). The carbon footprint of active sport tourists: An empirical analysis of skiers and boarders. Journal of Sport \& Tourism, 22(2), 151-171. https://doi.org/10.1080/14775085.2017.1313706

World Surf League. (2019a). PURE stop trashing waves - make the pledge today, \#StopTrashingWaves. https://www. worldsurfleague.com/posts/397638/pure_stw_neulion_1080?isearch=true\&scategory=all

World Surf League. (2019b). WSL pure. https://www.worldsurfleague.com/pure

World Tourism Organization. (2019). Sport tourism and sustainable development goals. https://webunwto.s3.eu-west1.amazonaws.com/s3fs-public/2019-09/sporttourismandsdgs.pdf

Zailani, S., Iranmanesh, M., Masron, T. A., \& Chan, T.-H. (2016). Is the intention to use public transport for different travel purposes determined by different factors? Transportation Research Part D: Transport and Environment, 49, 18-24. https://doi.org/10.1016/j.trd.2016.08.038 